\title{
TWO-PORT LAPAROSCOPIC APPENDECTOMY IS MORE BENEFECIAL THAN OPEN APPENDECTOMY IN EARLY ACUTE APPENDICITIS
}

\author{
Vicky S Budipramana \\ Department of Surgery, Dr. Soetomo Hospital, Faculty of Medicine, Universitas Airlangga, Surabaya
}

\begin{abstract}
ABSTRAK
Teknik open appendectomy biasa dilakukan untuk mengobati usus buntu akut, tetapi kesakitan dan masa pengobatan yang lama menimbulkan masalah kosmetik. Teknik two-port laparoscopic appendectomy dapat dilakukan dengan aman, tidak terlalu menyakitkan dan hanya menyisakan dua bekas luka sayatan kecil. Tujuan dari penelitian ini adalah untuk mengevaluasi manfaat dari teknik two-port laparoscopic appendectomy dengan teknik open appendectomy dalam kasus apendisitis akut dini. Metode observasional dilakukan dari tahun 2012-2014 untuk membandingkan waktu operasi, nyeri pasca operasi dan infeksi luka dalam apendisitis akut awal, yang dilakukan dengan teknik two-port laparoscopic appendectomy dan teknik open appendectomy. Analisis statistik dalam penelitian ini menggunakan t-test. Ada 114 Pasien (73 laki-laki dan 41 perempuan) dibagi menjadi dua kelompok berdasarkan pilihan yang dibuat oleh pasien. Jumlah sampel yang menggunakan teknik two-port laparoscopic appendectomy sebanyak 64, sedangkan teknik open appendectomy sebanyak 46. Empat Pasien dikeluarkan dari penelitian ini. Dalam analisis menggunakan t-tes, kami menemukan bahwa teknik two-port laparoscopic appendectomy lebih menguntungkan daripada teknik open appendectomy. Ada perbedaan yang signifikan antara kedua kelompok, dalam teknik two-port laparoscopic appendectomy, lamanya waktu operasi adalah 37,22 menit sedangkan teknik open appendectomy selama 43,83 menit (p = 0:00); skor nyeri VAS dalam teknik two-port laparoscopic appendectomy adalah 1:58 sedangkan teknik open appendectomy 2:30 ( $p=0: 00)$; tidak ada infeksi luka pasca-operasi di kedua kelompok. Simpulannya adalah teknik two-port laparoscopic appendectomy lebih cepat dan kurang menyakitkan serta tidak adanya risiko infeksi luka pada kedua teknik dalam apendisitis akut awal. (FMI 2016;52:131-135)
\end{abstract}

Kata kunci: awal apendisitis akut, teknik two-port laparoscopic appendectomy, teknik open appendectomy

\begin{abstract}
Open appendectomy has already commonly been performed to treat acute appendicitis, but the relatively more painful and longer incision scar becomes a cosmetical problem. Two port laparoscopic appendectomy can be performed safely, less painful and leaving only two small incision scars. The aim of the study was to evaluate the benefit of two-port laparoscopic appendectomy and that of with open appendectomy in the case of early acute appendicitis. An observational study was conducted from 2012 to 2014 ; to compare the operating time, post operative pain and wound infection in early acute appendicitis, performed with two-port laparoscopic appendectomy and with open appendectomy. The statistical analysis in this study uses t-test. There were 114 patients (73 men and 41 women) divided into two groups based on the choice made by the patients themselves. The number of samples performed with two-port laparoscopic appendectomy was 64 and that with open appendectomy was 46. Four patients were excluded from this study. In analysis using t-test, we found that the two-port laparoscopic appendectomy was more beneficial than open appendectomy. There was a significant difference between the two groups, the length of operation time was 37.22 minute in two-port laparoscopic appendectomy and 43.83 minute in open appendectomy $(p=0.00)$, VAS pain score was 1.58 in two-port laparoscopic appendectomy and 2.30 in open appendectomy $(p=0.00)$ and no post operative wound infection in both two groups. The conclusion is two-port laparoscopic appendectomy technique is faster and less painful and the same risk of wound infection than open appendectomy in early acute appendicitis. (FMI 2016;52:131-135)
\end{abstract}

Keywords: early acute appendicitis, two-port laparoscopic appendectomy, open appendectomy.

Correspondence: Vicky S. Budipramana, Department of Surgery, Dr. Soetomo Hospital, Faculty of Medicine, Universitas Airlangga, Surabaya. Phone: 081.131.5812. e-mail: vickysbudi@gmail.com

\section{INTRODUCTION}

Today, it can be stated that laparoscopic appendectomy is the gold standard for experienced laparoscopic surgeons. The procedure was introduced in 1983 by gynaecologist Kurt Semm (Edelman 1997). Since then the 'classic' laparoscopic technique with 3 or even 4 ports was modified and improved to produce minimal tissue trauma with faster recovery and better cosmesis (Yagnik et al 2010). Laparoscopic appendectomy is now considered to be a safe and excellent alternative to open appendectomy. Complicated appendicitis and poor risk for general anesthesia are considered to be relative contraindications for laparoscopic appendectomy. Traditional laparoscopic appendectomy (three-ports) did not offer much advantage over the open appendectomy 
due to prolonged operative time and higher cost (Bresciani et al 2005). Open appendectomy still confers benefit in terms of lesser incidence of intraabdominal abscess (Al Wadan et al 2010). The two-port technique is similar to the three-port technique, except that appendix is delivered through right-iliac fossa $10-12$ $\mathrm{mm}$ port, tied extracorporeally and removed. A few randomized con-trolled trials show that laparoscopic appendectomy is safe and effective for treatment of appendicitis with improvement in outcome (Towfigh et al 2006). Use of laparoscopy for appendectomy is generally recommend-ded to patients with suspected appendicitis unless laparoscopy itself is contraindicated or not feasible. According to Cochrane review published in 2004, there is certain advantage of laparoscopic appendectomy over open appendectomy (Sauerland et al 2004). The two-port laparoscopic appendectomy is also gaining popularity because of shorter operative time, lesser postoperative pain and lesser incidence of surgical site infection (Augustin et al 2013). Laparoscopic appendec-tomy has now become an important tool for treatment of those with undiagnosed abdominal pain for diagnostic-workup. Laparoscopic appendectomy, especially two-port, is found to be cost effective because of shorter operative time, significant early discharge from the hospital and lesser surgical site infection (Katkhouda et al 2005).

\section{MATERIALS AND METHODS}

An observational study was conducted from 2012 to 2014 ; involving patients operated by a single operator in private hospitals in Surabaya. The number of the patients was 114 (73 men and 41 women) with early acute appendicitis (4 cases excluded, 110 patients involved in this trial). Performed with two-port laparoscopic appendectomy $(n=64)$ versus with open appendectomy $(n=46)$. The allocation of the patients to either of the groups was based on the choice made by the patients themselves. The aim of this study was to compare the operating time, post operative pain and wound infection in early acute appendicitis, performed with two-port laparoscopic appendectomy and with open appendectomy. Early acute appendicitis is that the patients came to the hospital less than 24 hours from the first symptom, and the number of white blood cells was less than $11.000 / \mathrm{mm} 3$. The statistical analysis in this study uses t-test. Patients with complicated appendicitis like perforated appendicitis, appendicular abscess, lump and those with other intraabdominal pathology in addition to appendicitis, were excluded from the study. Patients converted to open procedure after initial diagnosis were also excluded from the study. Laparoscopic appendectomies in this study were done under general anesthesia and performed by a single surgeon qualified in doing laparoscopic appendectomy. Clinical assessment of acute appendicitis was confirmed by specific sign and symptoms of acute appendicitis, specific right lower abdominal pain, the number of white blood cells, and ultrasonography examination. Outcome was assessed in the form of the length of operation time, VAS pain score and post operative wound infection between the two groups. Antibiotics were administrated preoperatively to cover gramnegative and anaerobic organisms.

\section{Technique of Two Port Laparoscopic Appendectomy}

Pneumoperitoneum was created in a standard manner with Hasson technique in infraumbilical position. A 11 $\mathrm{mm}$ trocar was inserted for accommodating telescope and another $12 \mathrm{~mm}$ port was inserted by looking at the position of the appendix in the right lower quadrant. Appendix was identified by using the standard technique and it was grasped with either the Babcock forceps or a bowel grasper. Appendix was delivered through the right lower quadrant port; pneumo-peritoneum was deflated and appendicular artery was ligated on the mesenterium with silk 2-0 and cut. The stump of the appendix was doubled-ligated with silk 2-0. Hemostasis was checked with scope at the end. Closure of the umbilical as well as right iliac fossa port was done by Vicryl 2-0 and skin was closed subcutaneously. Patients in the open appendectomy, gridiron incision was made through Mc Burney point 4 or $5 \mathrm{~cm}$ long. All patients were followed up for 1 month to look for surgical site infections.

Inclusion criteria were patient aged between 12-65 years old with uncomplicated acute appendicitis, no concomitant metabolic or sistemic disease, characteristic physical sign of acute appendicitis, not more than 24 hours from the first symptom, WBC not more than 11.000 , and no other pathologies on abdominal USG. Exclusion criteria were complicated appendicitis found intra-operatively (perforated appendicitis, appendicular abscess or appendicular mass) or retrocaecally located appendix, other intra abdominal pathology found intraoperatively, and converted to open appendectomy.

\section{RESULTS}

Table 1. Four cases excluded from the study

\begin{tabular}{lccc}
\hline & Two-port & Open & Total \\
\hline Retrocaecal & - & 2 & 2 \\
Perforated & 1 & 1 & 2 \\
\hline & 1 & 3 & 4 \\
\hline
\end{tabular}


Table 2. The difference result of the two groups, the operating time (minutes), VAS score and wound infection.

\begin{tabular}{lccc}
\hline & $\begin{array}{c}\text { Two-port Lap } \\
\mathrm{n}=64\end{array}$ & $\begin{array}{c}\text { Open } \\
\mathrm{n}=46\end{array}$ & $\mathrm{P}$ \\
\hline Time (minute) & 37.22 & 43.83 & 0.00 \\
VAS score & 1.58 & 2.30 & 0.00 \\
\hline Wound infection & 0 & 0 & - \\
\hline
\end{tabular}

There was a significant difference between the two groups, the length of operation time was 37.22 minute in two-port laparoscopic appendectomy and 43.83 minute in open appendectomy $(\mathrm{p}=0.00)$, VAS pain score was 1.58 in two-port laparoscopic appendectomy and 2.30 open appendectomy $(\mathrm{p}=0.00)$ and no post operative wound infection between the two groups. A total of 114 patients (73 men and 41 women) were operated during 2011 to 2013 in many private hospitals in Surabaya.

The total number of the patients were randomly divided into two groups. The number of samples performed with two-port laparoscopic appendectomy was 64 and that with open appendectomy was 46 . Four patients were excluded from this study, because intraoperatively there were two cases of retrocaecally located appendix in open appendectomy group, and two cases of perforated appendicitis, one in two-port laparoscopic appendectomy group and one in open appendectomy group.

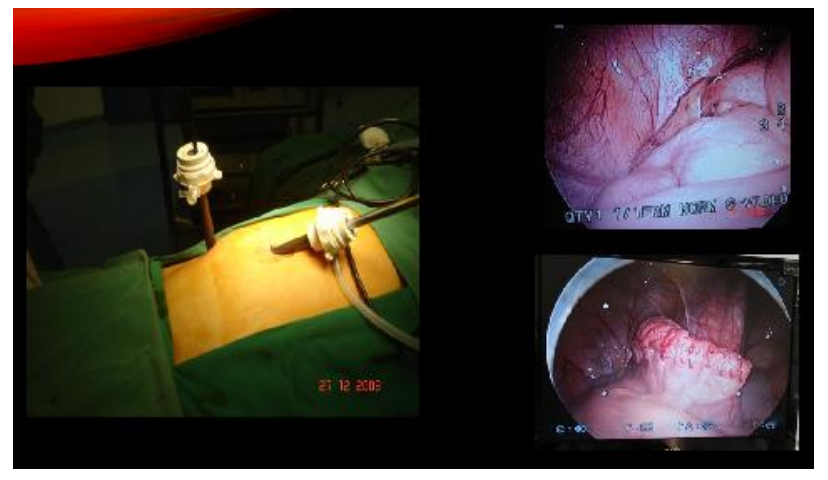

Fig 1. The position of the ports and intra abdominal view of the appendix

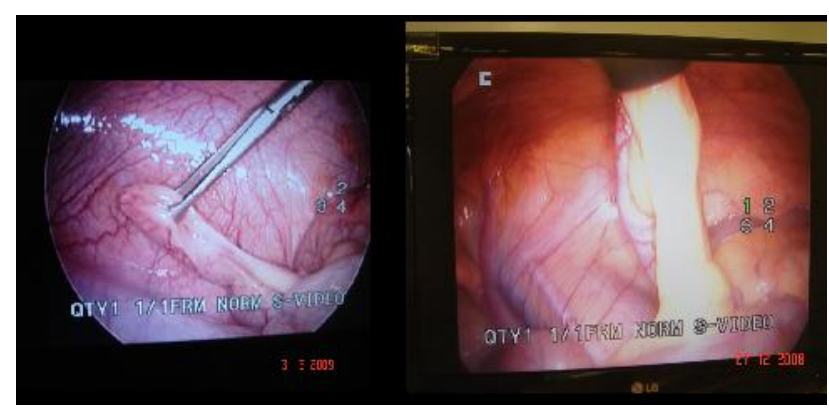

Fig 2. Appendix grasped with forceps and pulled through the port.

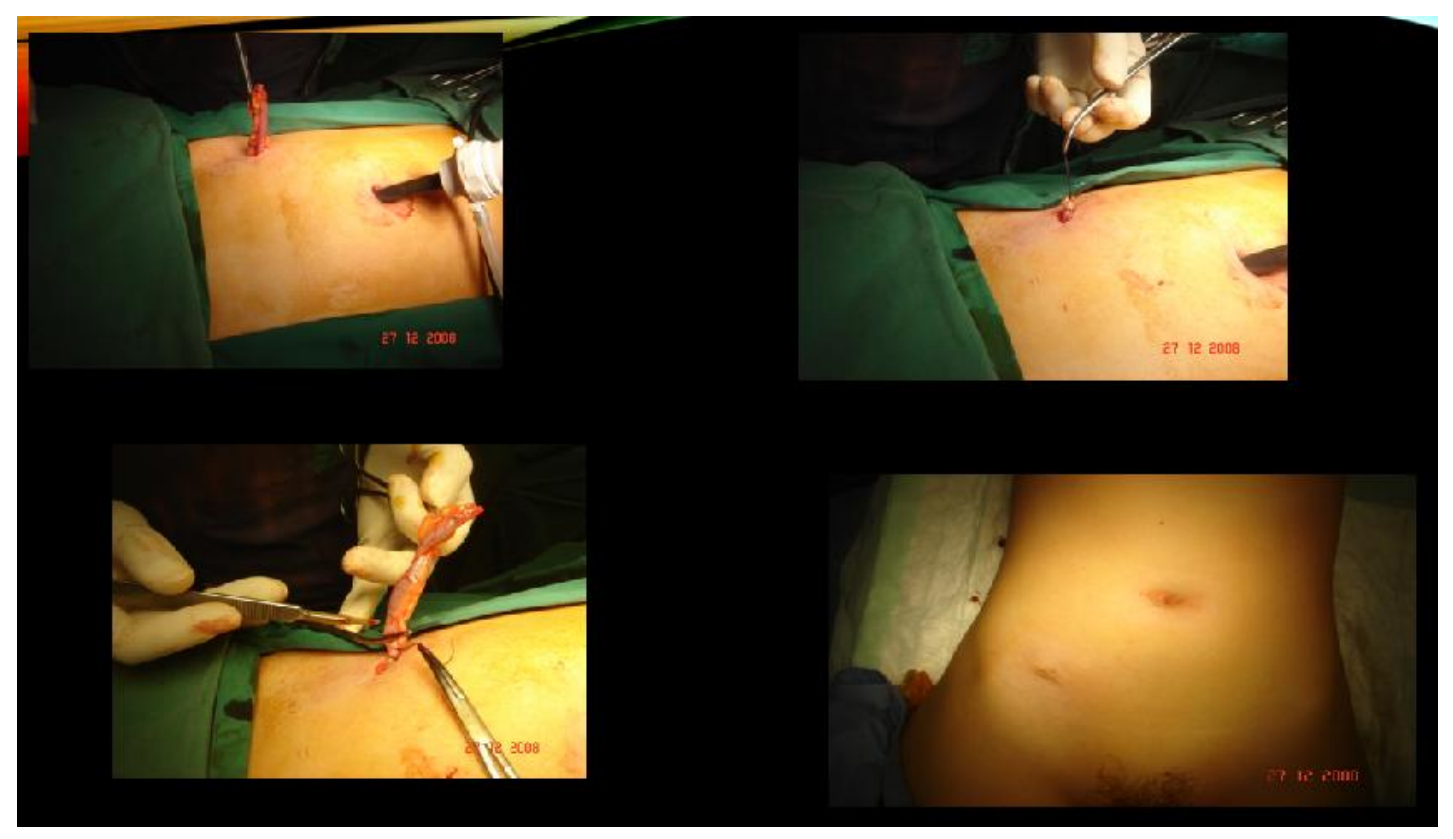

Fig 3. The process of cutting the appendix 
There was a significant difference between the two groups, the length of operation time was 37.22 minute in two-port laparoscopic appendectomy and 43.83 minute in open appendectomy $(\mathrm{p}=0.00)$, VAS pain score was 1.58 in two-port laparoscopic appendectomy and 2.30 open appendectomy $(p=0.00)$ and no post operative wound infection between the two groups. There was no post operative wound infection in the two groups, because of no touch technique done in all cases. The base of the appendix was cut in such a way that the process did not touch the skin and subcutaneous tissue, the stump of the appendix was also protected from touching the surrounding tissue. The stump of the appendix was wrapped with gauze and pushed back into the abdominal cavity.

\section{DISCUSSION}

The role of laparoscopic appendectomy as compared with open appendectomy is more benefecial and also, laparoscopic appendectomy has proved to be clearly beneficial in fat patients and in patients with a diagnostic dilemma (Katkhouda et al 2005). The laparos-copic appendectomy is also gaining popularity because of shorter operating time, less postoperative pain and similar incidence of surgical site infection. Nowadays, attempts have been made to reduce the number of ports inserted and improve cosmesis. The two-port technique is similar to the three-port technique, except that appendix is delivered through right iliac fossa $12 \mathrm{~mm}$ port and tied extracorporeally and removed. This technique was utilized by us for adult patient groups. Two-port technique has an additional advantage of more minimal tissue trauma ( $\mathrm{Li}$ et al 2010). Traditional laparoscopic appendectomy (threeports) did not offer much advantage over the open appendectomy due to prolonged operating time and higher cost (Bresciani et al 2005). Open appendectomy still gives benefit in terms of less intraabdominal abscess (Anhel 2012). The use of laparoscopy for appendectomy is generally recommended to patients with suspected appendicitis unless laparoscopy itself is contraindicated or not feasible (Suerland et al 2004).

In laparoscopic procedure, the tip of the appendix could be raised easily, its mesentery is mobile and it can be pulled out through the right port. With deflation of the peritoneal cavity and good abdominal wall relaxation, the rest of the procedure could be performed easily extracorporeally. We use $12 \mathrm{~mm}$ port as a routine to facilitate the procedure. There is no need for the $3 \mathrm{rd}$ port to save time and the cost as well, because of the use of another port, endo-loopes, and vascular clips (Costa 2013). If the caecum was fixed to the retroperitoneum and the appendix was difficult to mobilize, then the relaxed abdominal wall was pushed down by the assistant's hand to fasilitate the appendix pulled out through the right port. In some cases, especially in obese patients, the mesoappendix was very thick, the mesoappendix was difficult to pass through the relatively narrow $12 \mathrm{~mm}$ hole. In this case the muscle, but not the skin, was splitted wider to facilitate the appendix easy to be pulled outside (Doepker et al 2014). After the appendix was cut, the defect of the muscle closed with stitches.

Four patients were excluded from the study, 2 cases because of the retrocaecally-located appendix found intraoperatively in open appendectomy group, one patient in open appendectomy group and one patient in laparoscopic appendectomy group were also excluded because of perforation of the appendix found intraoperatively. Retrocaecaly located appendix was difficult to perform with two port technique because only one working port is available. The two-port laparoscopic apendicectomy is simple, easy to learn and has the combined advantages of open appendicectomy and full laparoscopic technique. It can be converted to open appendicectomy very quickly when required or to total intracorporeal approach by inserting additional ports (SAGES 2009). Compared to single port approach, twoport technique does not require expertise of operating telescope (Knott et al 2012). The cost can also be minimized by using reuseable ports. The overall morbidity of two-port laparoscopic apendicectomy is low. There was no specific complication related to this technique and the incidence of port site infection was similar to other approaches of laparoscopic appendicectomy. We did not encounter any increased risk of intraperitoneal abscess and abdominal wall abscess due to contamination during the procedure.

In our study, the mean operative time in two-port laparoscopic group was $37.22 \mathrm{~min}$, which is comparable to that reported in the study done by El-Gohary \& ElMarsafawy (2001) (34.4 min) and Adhikary et al (2008) have reported $23.3 \mathrm{~min}$. In our study, no surgical site infections noted, El-Gohary \& El-Marsafawy (2001) reported $0 \%$, while Adhikary et al (2008) reported 10\% surgical site -infection. Short-operative time in two-port technique was probably because of ease of operative technique and extra-corporeal knotting being easier and faster and also all the patients in the laparoscopy as well as open group belong to uncomplicated appendicitis. There was no case of surgical site infection in the two groups, probably because we included only uncomplicated acute appendicitis in this study. Though appendix is in the trocar hole and is inflamed, surgical site infection is not higher probably because of uncomplicated appendicitis and no touch technique performed. Laparoscopic appendectomy, especially 
two-port, is found to be cost effective because of shorter operative time, early discharge from the hospital and lesser surgical site infection. Psychological trauma associated with bigger dressing involved with routine dressing can also be minimized.

\section{CONCLUSION}

Two-port appendectomy has been found to be associated with significantly shorter operative time, less postoperative pain and no surgical site infection. The two-port laparoscopic technique is simple, easy to learn and has the combined advantages of open appendicectomy and full laparoscopic technique. It can be converted to open appendicectomy very quickly when required or changed to total intracorporeal approach by inserting accessory ports.

\section{REFERENCES}

Adhikary S, Tyagi G, Sapkota A, Afaq A, Bhattarai BK, Agrawal CS (2008). Port exteriorization appendectomy: is it the future?. Nepal Med Coll J 10, 30-34

Al Wadan A, Al Senebani J, Al Ahnoomi A, Al Saadi A (2010). Early complication and re-admission after laparoscopic and open appendectomy. Egyptian Journal of Surgery 29

Anhel K (2012). Complications during and after laparoscopic appendectomy. BH Surgery 2, 49-53

Augustin G, Matošević P, Mate M (2013). The lasso technique'-a simple intracorporeal two-port laparoscopic appendectomy: technical considerations and review of four other intracorporeal two-port techniques. Hepato-gastroenterology 60, 1058-1062

Bresciani C, Perez RO, Habr-Gama A, Jacob CE, Ozaki A, Batagello C, Proscurshim I, Gama-Rodrigues J (2005). Laparoscopic versus standard appendectomy outcomes and cost comparisons in the private sector. $\mathrm{J}$ Gastrointest Surg 9, 1174-1181

Bresciani C, Perez RO, Habr-Gama A, Jacob CE, Ozaki A, Batagello C, Proscurshim I, Gama-Rodrigues J (2005). Laparoscopic versus standard appendectomy outcomes and cost comparisons in the private sector. $\mathbf{J}$ Gastrointest Surg 9, 1174-1181
Costa N (2013). Laparoscopic appendectomy quality care and cost-effectiveness for todays' economy. World Journal of Emergency Surgery 8, 45

Doepker MP, Gregg JL, Meeker G, Ellis B, Grannan K (2014). Does the use of newer technology to divide the mesoappendix result in less bleeding? a retrospective analysis. Journal of Current Surgery 4, 69

Edelman D (1997). Laparoscopic appendectomy versus open appendectomy: a single institution study. Journal of the Society of Laparoendoscopic Surgeons 1

El-Gohary MA and El-Marsafawy M (2001). Portexteriorization appendectomy (PEA): a preliminary report. Pediatr Surg Int 17, 39-41

Katkhouda N, Mason RJ, Towfigh S, Gevorgyan A, Essani R (2005). Laparoscopic versus open appendectomy: a prospective randomized doubleblind study. Ann Surg 242, 439-450

Knott EM, Gasior AC, Holcomb III GW, Ostlie DJ, St Peter SD (2012). Impact of body habitus on single-site laparoscopic appendectomy for nonperforated appendicitis: subset analysis from a prospective, randomized trial. Journal of Laparoendoscopic \& Advanced Surgical Techniques 22, 404-407

Li X, Zhang J, Sang L, Zhang W, Chu Z, Li X, Liu Y (2010). Laparoscopic versus conventional appendectomy- a meta-analysis of randomized controlled trials. BMC Gastroenterology 10, 129

SAGES (2009). Guidelines for laparoscopic appendectomy, SAGES Society of American Gastrointestinal and Endoscopic Surgeons. Available from http://www.sages.org. Accessed October 15, 2015

Sauerland S, Lefering R, Neugebauer EA (2004). Laparoscopic versus open surgery for suspected appendicitis. The Cochrane Library

Towfigh S, Chen F, Mason R, Katkhouda N, Chan L, Berne $T$ (2006). Laparoscopic appendectomy significantly reduces length of stay for perforated appendicitis. Surgical Endoscopy and Other Interventional Techniques 20, 495-499

Yagnik VD, Rathod JB, Phatak AG (2010). A retrospective study of two-port appendectomy and its comparison with open appendectomy and three-port appendectomy. Saudi Journal of Gastroenterology 16, 268-271 